DOI: $10.19195 / 0137-1134.117 .11$

\title{
ARTUR TOMANEK
}

ORCID: 0000-0002-3287-5886

Uniwersytet Wrocławski

\section{KLAUZULE AUTONOMICZNE UMÓW O PRACĘ- ZAGADNIENIA POJECCIOWE}

\begin{abstract}
Abstrakt: Punktem wyjścia rozważań jest pojęcie klauzuli autonomicznej umowy o pracę, wprowadzone do piśmiennictwa polskiego przez Macieja Święcickiego. Autor niniejszego opracowania uznaje, że stronom stosunku pracy przysługuje swoboda co do uzupełnienia jego treści o klauzule autonomiczne. Klauzule te są umowami odrębnymi od umów o pracę, co znajduje wyraz w szczególnym ukształtowaniu reguł ich obowiązywania, zmian i rozwiązywania. Regulują one prawa i obowiązki należące do stosunku pracy, odróżniając się pod tym względem od innych umów prawa pracy oraz umów cywilnoprawnych zawieranych przez pracownika i pracodawcę. Ograniczenia zakresu materii prawnej regulowanej na drodze klauzul autonomicznych wynikają z natury (charakteru) tych klauzul oraz umów głównych — umów o pracę.
\end{abstract}

Słowa kluczowe: klauzula autonomiczna, stosunek pracy, umowa o pracę, umowa cywilnoprawna

\section{WPROWADZENIE}

Pojęcie „klauzula autonomiczna” umowy o pracę zostało wprowadzone do języka prawniczego przed kodyfikacją prawa pracy. Autor tego pojęcia, Maciej Święcicki, podał następujące jego cechy:

- klauzule autonomiczne kształtują treść stosunku pracy,

- roszczenia z nich wynikające są roszczeniami ze stosunku pracy,

— do oceny ich powstania i ustania stosuje się ogólne zasady rządzące stosunkiem pracy, a w dziedzinie procesowej — zasady dotyczące rozstrzygania sporów ze stosunku pracy.

M. Święcicki wskazał jednocześnie, że akcydentalność klauzul autonomicznych upodabnia je do zastrzeżeń umownych, jednak ich treść, choć włączona do stosunku pracy, może być z niego usunięta, nie naruszając jego trwania. W związku z tym klauzule te są zależne od stosunku pracy, ale nie angażują jego istnienia ${ }^{1}$.

Założenia przyjęte przez M. Święcickiego nie były zasadniczo podważane w późniejszym piśmiennictwie, które posługuje się wypracowaną przez tego autora aparaturą pojęciową, dodając niekiedy, że bardziej stosownym terminem byłaby 
„umowa uzupełniająca” lub „umowa dodatkowa” do umowy o pracę². Wyjątkiem było stanowisko Tadeusza Zielińskiego, jednak badacz ten koncentrował swoją uwagę na charakterze prawnym umów kształtujących grupową organizację pracy, uznając - w przeciwieństwie do M. Święcickiego - że takie umowy nie tworzą sumy klauzul autonomicznych zawieranych z pracodawcą przez pracowników wchodzących w skład zespołu roboczego, lecz są umowami prawnie samodzielnymi ${ }^{3}$.

Zgodność ocen doktrynalnych ma jednak charakter pozorny. W wypowiedziach, które odnoszą się zwykle do konkretnych typów klauzul, ujawniają się daleko idące różnice co do zakresu pojęcia klauzul autonomicznych, co prowadzi niekiedy do sprzeczności z jego pierwotnym ujęciem. Nie jest zatem jasne, na czym polega odrębność (autonomia) omawianych klauzul w stosunku do umowy o pracę. $Z$ jednej strony wskazuje się, że klauzule te są czynnościami prawnymi odrębnymi od umowy o pracę ${ }^{4}$, jednak nierozerwalnie związanymi ze stosunkiem pracy oraz kształtującymi prawa i obowiązki stron tego stosunku ${ }^{5}$. Należy również odnotować stanowisko, według którego do klauzul autonomicznych można zaliczyć umowy zdefiniowane normatywnie jako cywilnoprawne, jeżeli dotyczą one zobowiązań stron mieszczących się w stosunku pracy ${ }^{6}$. Z drugiej strony twierdzi się, że klauzule autonomiczne należą do postanowień umowy o pracę ${ }^{7}$, mocą których strony uzgadniają dodatkowe zespoły praw i obowiązków, zachowujących odmienny od umowy o pracę byt prawny ${ }^{8}$. W tym samym nurcie mieści się stwierdzenie, że klauzule te modyfikują podstawową treść stosunku pracy, w odróżnieniu od umów prawa pracy zawieranych przez pracodawcę i pracownika, które dotyczą kwestii wykraczających poza prawa i obowiązki pracownika związane ze świadczeniem pracy ${ }^{9}$. Można również spotkać się z wypowiedziami utożsamiającymi klauzule autonomiczne z podmiotowo istotnymi składnikami umów o pracę ${ }^{10}$.

2 J. Jończyk, Prawo pracy, Warszawa 1984, s. 412-413; J. Stencel, Zakaz konkurencji w prawie pracy, Warszawa 2001, s. 114-117.

3 T. Zieliński, ,Umowy nienazwane” w grupowym systemie czasu pracy, „Ruch Prawniczy, Ekonomiczny i Społeczny" 1988, nr 1, s. 73 n.

4 B. Wagner, Zakres swobody umów w pracowniczym stosunku pracy, Kraków 1986, s. 120; J. Stencel, op. cit., s. 116-117; T. Liszcz, [w:] System Prawa Pracy, t. 2. Indywidualne prawo pracy. Część ogólna, red. G. Goździewicz, Warszawa 2017, s. 299.

5 M. Zieleniecki, [w:] Prawo pracy, red. J. Stelina, Warszawa 2018, s. 371.

${ }^{6}$ K. Jaśkowski, [w:] Kodeks pracy. Komentarz. Ustawy towarzyszace z orzecznictwem, red. K. Jaśkowski, E. Maniewska, Warszawa 2019, s. 261.

7 W. Szubert, Zarys prawa pracy, Warszawa 1976, s. 112-113; W. Piotrowski, Stosunek pracy, Poznań 1977, s. 40.

8 J. Stelina, [w:] Prawo pracy, red. J. Stelina, Warszawa 2018, s. 147.

9 P. Prusinowski, Nienazwane umowy zawierane przez strony stosunku pracy, „Monitor Prawa Pracy" 2011, nr 20, s. 1124.

10 A. Patulski, Zatrudnianie i wynagradzanie kadry menedżerskiej średniego i wyższego szczebla, Gdańsk 2001, s. 51. 


\section{SWOBODA ZAWIERANIA KLAUZUL AUTONOMICZNYCH ORAZ ICH ODRĘBNOŚĆ OD UMÓW O PRACĘ}

Przepisy kodeksu pracy pozwalają na wyróżnienie innych, oprócz umowy o pracę i spółdzielczej umowy o pracę, umów indywidualnego prawa pracy, które nie są aktami nawiązującymi stosunek pracy (art. 2 k.p.), ale mogą współkształtować sytuację prawną stron tego stosunku. Do tej kategorii można zaliczyć: umowę o zakazie konkurencji w czasie trwania stosunku pracy (art. $101^{1}$ k.p.) i po jego ustaniu (art. $101^{2}$ k.p.), umowę szkoleniową (art. $103^{4}$ k.p.), porozumienie szkoleniowe (art. $103^{6}$ k.p.), umowę o wspólnej odpowiedzialności materialnej (art. 125 k.p.), a także umowę o warunkach wykonywania telepracy (art. $67^{11} \S 2$ k.p.). Umowy te wykazują funkcjonalną zależność od stosunku pracy, ponieważ ich nawiązanie oraz byt prawny są uwarunkowane skutecznym nawiązaniem tego stosunku. Nie prowadzi to jednak automatycznie do uznania, że wszystkie wymienione umowy są klauzulami autonomicznymi. Przymiot ten należy bowiem wiązać jedynie z tymi umowami, które regulują treść stosunku pracy. Zakres i cel niniejszego opracowania nie pozwala na szczegółową analizę charakteru prawnego wymienionych typów umów. Można jednak ocenić, że wskazane kryterium spełnia większość z nich, poza umową o zakazie konkurencji po ustaniu stosunku pracy (art. 101² k.p.).

We wskazanych sytuacjach decyzja ustawodawcza przesądza o wyodrębnieniu określonych umów poza ramy umowy o pracę. Klauzula autonomiczna zachowuje samodzielny byt prawny, chociaż pozostaje w ścisłym związku z umową główną (umową o pracę). Odrębność ta jest zaakcentowana najbardziej w wypadku umowy o zakazie konkurencji oraz umowy o wspólnej odpowiedzialności materialnej. Przepisy określają bowiem wyraźnie formę zawarcia względnie tryb zmian i ustania tych umów, odbiegający od sposobu uregulowania analogicznych kwestii w odniesieniu do umowy o pracę, używając jednocześnie zwrotu „odrębna umowa"11. Nie ma zatem istotnego znaczenia, czy umowa główna oraz klauzula autonomiczna zostały ujęte w jednym dokumencie. Takie usytuowanie klauzuli nie może uchylić jej odrębnego charakteru.

W dalszej kolejności należy zwrócić uwagę na przepisy niektórych aktów ustawowych, które wskazują na możliwość uzgodnienia określonych spraw przez pracodawcę i pracownika na drodze umowy, jednak operują fragmentarycznym unormowaniem, więc nie mogą zostać uznane za podstawę wyodrębnienia umów nazwanych według kryteriów przyjętych w cywilistyce ${ }^{12}$, które winny mieć zastosowanie do zobowiązaniowego stosunku pracy. Mieszczą się tutaj regulacje upoważniające do umownego ustalenia majątkowych uprawnień pracownika i pracodawcy

11 Zob. odp. art. $101^{1}-101^{3}$ k.p. oraz art. $125 \S 1$ k.p. i rozporządzenie Rady Ministrów z dnia 4 października 1974 roku w sprawie wspólnej odpowiedzialności materialnej pracowników za powierzone mienie (tekst jedn. Dz.U. z 1996 r. Nr 143, poz. 662).

12 O tych kryteriach zob. A. Brzozowski, [w:] System Prawa Prywatnego, t. 5. Prawo zobowiązań - część ogólna, red. E. Łętowska, Warszawa 2006, s. 407 oraz powołana tam literatura. 
do utworów (art. 12 ust. 1 ustawy z dnia 4 lutego 1994 roku o prawie autorskim i prawach pokrewnych ${ }^{13}$ ) oraz wynalazków i programów komputerowych (art. 11 ust. 3 i art. 74 ust. 3 ustawy z dnia 30 czerwca 2000 roku — Prawo własności przemysłowej ${ }^{14}$ ), dokonanych w wyniku wykonywania obowiązków ze stosunku pracy, oraz okresu przestrzegania przez pracownika tajemnicy przedsiębiorstwa po ustaniu zatrudnienia ${ }^{15}$. Przepisy te odsyłają ogólnie do ustaleń umownych poczynionych przez strony (art. 11 ust. 2 u.p.w.p., art. 11 ust. 2 u.z.n.k.) lub dokonanych w umowie o pracę (art. 12 ust. $1 \mathrm{i}$ art. 14 ust. 1 u.p.a.) lub innej umowie (art. 74 ust. 3 u.p.a.). Taka ich treść skłania do wniosku, że odpowiednie uzgodnienie stron może być zamieszczone zarówno w samej umowie o pracę, jak i w umowie odrębnej.

Pozostaje do rozstrzygnięcia, czy w celu uregulowania zagadnień akcydentalnych, uznanych za istotne przez strony stosunku pracy, pracownik i pracodawca mogą zawierać umowy nieunormowane w żaden sposób w przepisach prawa, wprowadzające do treści stosunku pracy elementy autonomiczne. W mojej ocenie odpowiedź na to pytanie jest pozytywna ${ }^{16}$. Kodeks pracy zawiera wprawdzie wyczerpujący katalog podstaw nawiązania stosunku pracy (art. 2 k.p.) oraz rodzajów umów o pracę (art. 25 k.p.), co upoważnia do stwierdzenia, że nie jest dopuszczalne zawarcie umowy niewymienionej $\mathrm{w}$ tych przepisach, która prowadziłaby do nawiązania stosunku pracy ${ }^{17}$. Założenie to nie może być jednak rozciągane na sferę umów będących klauzulami autonomicznymi, które regulują kwestie akcydentalne i są funkcjonalnie podrzędne wobec umowy głównej - umowy o pracę. Swobody zawierania takich umów nie ogranicza art. 18 k.p. dotyczący zagadnienia innego rodzaju — rozstrzygający kolizję między wolą stron a normą prawną w kierunku nieważności postanowień umownych sprzecznych z normami semiimperatywnymi, kształtującymi sytuację pracownika $(\S 1-2)^{18}$, a także postanowień naruszających zasadę równego traktowania w zatrudnieniu $(\S 3)^{19}$. Nie oznacza to, że zakres materii podlegającej regulacji na drodze klauzul autonomicznych jest nielimitowany. Ograniczenia mogą być bowiem wywodzone z natury prawnej tych klauzul, które

13 Tekst jedn. Dz.U. z 2019 r. poz. 1191 ze zm. (dalej: u.p.a.). Zob. też art. 14 ust. 1 tej ustawy.

14 Tekst jedn. Dz.U. z 2017 r. poz. 776 ze zm. (dalej: u.p.w.p.). Zob. też art. 22 ust. 1-3 tej ustawy.

15 Zob. art. 11 ust. 2 ustawy z dnia 16 kwietnia 1993 roku o zwalczaniu nieuczciwej konkurencji (tekst jedn. Dz.U. z 2018 r. poz. 418 ze zm.; dalej: u.z.n.k.) w brzmieniu obowiązującym przed jej znowelizowaniem ustawą z dnia 5 lipca 2018 roku o zmianie ustawy o zwalczaniu nieuczciwej konkurencji oraz niektórych innych ustaw (Dz.U. poz. 1637).

16 Podobnie w piśmiennictwie; zob. T. Zieliński, op. cit., s. 85; L. Florek, Ustawa i umowa w prawie pracy, Warszawa 2010, s. 125; P. Prusinowski, op. cit., s. 1123.

17 Z. Kubot, Umowa nienazwana jako podstawa powstania stosunku pracy?, [w:] Prawo pracy, zabezpieczenie społeczne (z aktualnych zagadnień), red. B.M. Ćwiertniak, Opole 2001, s. 29-31.

18 Zob. B. Wagner, Zasada swobody umów w prawie pracy, „Państwo i Prawo” 1987, nr 6, s. 75.

19 Odrębną kwestią jest to, czy do oceny ważności postanowień zawartych w klauzulach autonomicznych należy stosować zasadę uprzywilejowania pracownika (art. 18 § 1 i 2 k.p.). 
mają charakter uboczny w stosunku do umowy o pracę. Kwestia ta zostanie poruszona w dalszej części opracowania. Można jednak sformułować generalną uwagę, że dopuszczalność nawiązywania klauzul autonomicznych powinna być weryfikowana przy odwołaniu się do kryteriów wymienionych w przepisie art. $353^{1}$ in fine k.c., mającym zastosowanie na zasadzie art. 300 k.p.

Przytoczone rozważania znajdują potwierdzenie w praktyce stosowania prawa, w której występują następujące, przykładowo wymienione, klauzule autonomiczne: umowa przewidująca dla pracownika dodatkowe korzyści majątkowe (na przykład ubezpieczenie cywilne lub zdrowotne) lub określająca zasady korzystania ze sprzętu służbowego, umowa o indywidualnym powierzeniu pracownikowi składników mienia $\mathrm{z}$ obowiązkiem jego zwrotu lub wyliczenia się oraz umowa o zwolnieniu pracownika $\mathrm{z}$ obowiązku wykonywania pracy w okresie wypowiedzenia ${ }^{20}$. Umowy te należy traktować jako klauzule autonomiczne nienazwane.

W moim przekonaniu strony umowy o pracę zachowują również swobodę wyboru co do tego, czy w celu uregulowania określonej materii składającej się na ich prawa i obowiązki nawiązać odrębną (nienazwaną) umowę prawa pracy, czy też wprowadzić stosowne uzgodnienia do treści umowy o pracę. W tym drugim wypadku umowa o pracę zostaje wzbogacona o dodatkowe warunki pracy i/lub płacy, niewymienione w treści art. $29 \S 1$ k.p., który nie operuje enumeratywnym wyliczeniem tych warunków. Jeżeli zatem uznajemy dopuszczalność nawiązywania nienazwanych umów prawa pracy, kształtujących prawa i obowiązki pracownika i pracodawcy, to należy założyć, że w ramach przysługującej stronom autonomii mieści się decyzja co do unormowania tych kwestii w umowie o pracę lub innej, związanej z nią umowie.

Przyjmując, że stosunek pracy ma charakter złożony, należy uznać, że na treść klauzuli autonomicznej składa się uregulowanie jednego lub kilku stosunków elementarnych współtworzących stosunek złożony ${ }^{21}$. Rozstrzygnięcie, czy postanowienia uzgodnione przez strony stanowią jedną umowę o pracę, czy też rozdzielają się na dwie umowy lub większą ich liczbę (umowę główną i klauzule autonomiczne), musi uwzględniać zgodną wolę stron ${ }^{22}$ (art. $65 \S 2$ k.c. w zw. z art. 300 k.p.). Odwołanie się do kryterium subiektywnego nie zawsze pozwala na osiągnięcie satysfakcjonującego rezultatu, co nakazuje analizę elementów obiektywnych, świadczących o homogeniczności lub rozdzielności zawartych umów. Istotne znaczenie należy wiązać ze stopniem wyodrębnienia materii tworzącej przedmiot klauzuli, a także okolicznościami i czasem jej zawarcia, nie wyłączając

20 Treść art. $36^{2}$ k.p. nie stoi moim zdaniem na przeszkodzie zawieraniu takich umów.

21 O stosunkach prawnych elementarnych i złożonych zob. m.in. Z. Ziembiński, Problemy podstawowe prawoznawstwa, Warszawa 1980, s. 361-364; P. Machnikowski, [w:] System Prawa Prywatnego, t. 5, s. 110-111. Por. koncepcja elementarnych stosunków prawnych wyróżnionych w obrębie stosunku pracy przez Z. Kubot, Pozycja prawna stron w umownym stosunku pracy, Wrocław 1978, s. 25-32.

22 Z. Radwański, Teoria umów, Warszawa 1977, s. 232. 
również formalnej (dokumentowej) odrębności umowy o pracę i umowy uzupełniającej, która przemawia za dwoistością stosunków umownych.

Wśród wskazanych elementów doniosłą funkcję pełni identyfikacja ustawowego lub umownego reżimu zmiany i rozwiązania klauzuli autonomicznej, który różni się od trybu przewidzianego w przepisach kodeksu pracy dla umowy o pracę, pozwalając na modyfikację klauzuli lub jej usunięcie bez uszczerbku dla bytu i treści umowy o pracę. Przepisy działu II k.p. zawierają znacznie rozbudowaną, w porównaniu do umów cywilnoprawnych, regulację zmiany warunków pracy i płacy oraz ustania (rozwiązania i wygaśnięcia) umowy o pracę. Wynika to przede wszystkim $\mathrm{z}$ chęci zagwarantowania pracownikowi wzmożonej ochrony przed rozwiązaniem tej umowy i jednostronną zmianą jej warunków przez pracodawcę. Przepisy te wprowadzają ujednolicony, poza wyraźnymi wyjątkami ${ }^{23}$, tryb zmiany umownych warunków pracy i płacy na drodze czynności prawnych — porozumienia zmieniającego lub wypowiedzenia zmieniającego (art. $42 \S 1$ k.p.). Innymi słowy umowa o pracę jako typ umowy została wyraźnie powiązana $\mathrm{z}$ określonym sposobem jej ekspiracji lub zmiany jej treści. Trudno zatem sobie wyobrazić, aby poszczególne elementy jej treści podlegały odmiennym reżimom zmian, wywodzonym odpowiednio z reguł kodeksowych i autonomii woli stron. Taki wariant wydaje się dysfunkcjonalny, ponieważ wprowadza chaos co do możliwych sposobów zmiany warunków umownych, prowadząc do sztucznego rozczłonkowania treści umowy o pracę. Dlatego w razie wątpliwości należy uznać, że uregulowanie przez strony umowy o pracę określonego zespołu ich praw i obowiązków, połączone $\mathrm{z}$ ustaleniem autonomicznego trybu ich zmiany lub usunięcia z obrotu prawnego, składa się na odrębną umowę dotyczącą stosunku pracy, traktowaną jako klauzula autonomiczna.

\section{PRZEDMIOT REGULACJI KLAUZUL AUTONOMICZNYCH}

Na drodze klauzul autonomicznych kształtowane są uprawnienia i obowiązki pracownika oraz pracodawcy - stron stosunku pracy. Stosunek pracy jest stosunkiem zobowiązaniowym prawa pracy. Mimo licznych związków między indywidualnym prawem pracy i prawem cywilnym stosunek pracy nie może zostać uznany za stosunek prawa cywilnego. Należy zatem przyjąć, że treść stosunku pracy może być regulowana wyłącznie umową prawa pracy, nie zaś umową prawa cywilnego, która kształtuje stosunki cywilnoprawne między osobami fizycznymi i osobami prawnymi (art. 1 k.c.). Z tego względu umowa cywilnoprawna, której stronami są pracownik i pracodawca, nie jest klauzulą autonomiczną umowy o pracę. Pracownik i pracodawca mogą zawierać umowy prawa cywilnego, które pozostają w luźniej-

${ }^{23}$ Zob. np. art. $67^{8} \S 1$ i 2 k.p. 
szym lub ściślejszym związku ze stosunkiem pracy ${ }^{24}$. Spory dotyczące roszczeń wynikających $\mathrm{z}$ takich umów mogą być, w niektórych przypadkach, traktowane pod względem procesowym jako sprawy o roszczenia związane ze stosunkiem pracy (art. $476 \S 1$ pkt 1 k.p.c.), co nie oznacza jednak, że umowa tworząca podstawę wywodzenia tych roszczeń jest umową prawa pracy, a zwłaszcza - klauzulą autonomiczną umowy o pracę.

Poczynione założenia wymagają kilku zastrzeżeń. Po pierwsze, znane są umowy, które wywołują kontrowersje co do ich prawnopracowniczego lub cywilnoprawnego charakteru. Sztandarowym przykładem jest umowa o zakazie konkurencji po ustaniu stosunku pracy (art. $101^{2}$ k.p.), która jest oceniana jako umowa cywilnoprawna uregulowana w kodeksie pracy bądź jako umowa prawa pracy, przybierająca lub nie charakter klauzuli autonomicznej ${ }^{25}$. Wątpliwości dotyczą również innych umów, spośród których można wymienić porozumienie szkoleniowe (art. $103^{6}$ k.p.), a także umowę ustalającą majątkowe uprawnienia stron stosunku pracy do utworu (art. 12 ust. 1 i art. 74 ust. 3 u.p.a.) lub patentu (art. 11 ust. 3 u.p.w.p.). Nie wdając się w tym miejscu w szczegółowe rozważania charakteru prawnego wskazanych umów, należy stwierdzić, że ewentualna cywilistyczna kwalifikacja wyklucza możliwość uznania ich za klauzule autonomiczne umów o pracę.

Nie można apriorycznie odrzucić występowania umów zawierających kombinację elementów nazwanej lub nienazwanej umowy prawa cywilnego oraz elementów, które mogą zostać uznane za uzupełnienie treści stosunku pracy. Problematyka umów mieszanych odznaczających się taką charakterystyką była już sygnalizowana w dawniejszym piśmiennictwie na tle orzecznictwa Sądu Najwyższego ${ }^{26}$. Realia społeczne i ekonomiczne właściwe nowoczesnej gospodarce rynkowej odzwierciedlają się w złożonym układzie stosunków umownych, który może ad casum cechować się tak rozumianą „podwójną” kwalifikacją — zagadnienie to wymaga oddzielnej i pogłębionej refleksji. Niemniej jednak, posługując się teorią kombinacji lub analogii jako metodą prawnej oceny skutków powodowanych przez umowę mieszaną ${ }^{27}$, możliwe byłoby zastosowanie przepisów prawa pracy i przepisów prawa cywilnego do dających się wydzielić części umowy lub zobowiązań umownych podjętych przez strony.

Po wtóre, należy zwrócić uwagę na sytuacje, w których umowa określona przez strony lub ustawę jako cywilnoprawna przedstawia się w istocie jako klau-

24 Przykładami mogą być umowa, na mocy której pracodawca udziela pracownikowi pożyczki, a także niektóre umowy, których przedmiotem jest udostępnienie przez pracownika własnego sprzętu na potrzeby związane ze świadczeniem pracy.

25 Szerzej zob. A. Tomanek, Charakter prawny klauzuli konkurencyjnej (art. 101² k.p.), ,Przegląd Sądowy" 2014, nr 10, s. 37-41.

26 T. Zieliński, Glosa do uchwały SN z 22 października 1987 r., III CZP 55/87, „Państwo i Prawo" 1991, nr 2, s. 111-112; idem, ,,Umowy nienazwane”..., s. 84-85.

27 Szerzej o teoriach oceny prawnej umów mieszanych zob. B. Gawlik, Umowy mieszane konstrukcja i ocena prawna, „Palestra” 1974, nr 5, s. 30-32. 
zula autonomiczna umowy o pracę. Kwestia jest prostsza, jeżeli strony umowy o pracę zawierają jednocześnie umowę o świadczenie usług (art. 750 k.c. w zw. z art. $734 \S 1$ k.c.) nakładającą na pracownika dodatkowy obowiązek (zadanie robocze) wykonywany w warunkach zdefiniowanych przez art. $22 \S 1$ k.p., co uzasadnia ocenę, że strony zawarły klauzulę autonomiczną określającą dodatkową funkcję zawodową pełnioną przez pracownika ${ }^{28}$. Bardziej złożony problem sygnalizują te orzeczenia Sądu Najwyższego w sprawach pracowniczych, które dopatrują się występowania klauzul autonomicznych również w przypadkach, gdy strony zawierają umowę, która jest nominowana przez ustawodawcę jako cywilnoprawna. Według art. 34a ust. 1 ustawy z dnia 6 września 2002 roku o transporcie drogowym ${ }^{29}$ oraz przepisów wykonawczych do tej ustawy ${ }^{30}$ pojazdy niebędące własnością pracownika mogą być używane do celów służbowych ,na podstawie umów cywilnoprawnych", zawieranych między pracownikiem i pracodawcą. Tymczasem SN wskazał, że pracodawca jest zobowiązany do zwrócenia wszelkich kosztów związanych z pracą poniesionych przez pracownika, co uzasadnia ocenę, że umowa ta - wbrew deklaracji ustawodawczej - jest odrębną umową prawa pracy, ściśle związaną ze stosunkiem pracy ${ }^{31}$.

Z kolei art. $22^{4}$ ust. 2 zd. 1 ustawy z dnia 6 lipca 1982 roku o radcach prawnych ${ }^{32}$ stanowi, że radca prawny zatrudniony w charakterze pracownika jest uprawniony do dodatkowego wynagrodzenia w wysokości nie niższej niż 65\% kosztów zastępstwa sądowego zasądzonych na rzecz strony przez niego zastępowanej lub jej przyznanych w ugodzie, postępowaniu polubownym, arbitrażu zagranicznym lub w postępowaniu egzekucyjnym, jeżeli koszty te zostały ściągnięte od strony przeciwnej. W orzecznictwie wywodzi się, że dodatkowe wynagrodzenie z tytułu zastępstwa sądowego stanowi składnik wynagrodzenia za pracę, co znajduje potwierdzenie w ust. 1 powołanego przepisu ${ }^{33}$. Jego ust. 2 przewiduje jednak w zdaniu drugim, że „w państwowych jednostkach sfery budżetowej wysokość i termin wypłaty [dodatkowego - A.T.] wynagrodzenia określa umowa cywilnoprawna". Powstaje zatem istotny dysonans między uprawnieniami radców zatrudnionych w niepaństwowych i państwowych jednostkach organizacyjnych, skoro w pierwszym przypadku dodatkowe wynagrodzenie miałoby wynikać z przepisu ustawy

28 Osoba wykonująca funkcję dodatkową będzie uznana za pracownika w rozumieniu prawa ubezpieczeń społecznych. Zob. art. 8 ust. 2a ustawy z dnia 13 października 1998 roku o systemie ubezpieczeń społecznych (tekst jedn. Dz.U. z 2019 r. poz. 300 ze zm.).

29 Tekst jedn. Dz.U. z 2019 r. poz. 58 ze zm.

30 Paragraf 1 ust. 1 rozporządzenia Ministra Infrastruktury z dnia 25 marca 2002 roku w sprawie warunków ustalania oraz sposobu dokonywania zwrotu kosztów używania do celów służbowych samochodów osobowych, motocykli i motorowerów niebędących własnością pracodawcy (Dz.U. Nr 27, poz. $271 \mathrm{ze} \mathrm{zm}$.).

31 Tak Sąd Najwyższy w wyroku z dnia 13 listopada 2013 roku, sygn. I PK 94/13, OSNP 2015, nr 1, poz. 4 .

32 Tekst jedn. Dz.U. z 2018 r. poz. 2215 ze zm.

33 Wyrok SN z dnia 6 lipca 2011 roku, sygn. II PK 17/11, OSNP 2012, nr 17-18, poz. 218. 
i być składnikiem wynagrodzenia za pracę, w drugim zaś — przysługiwać jedynie na podstawie umowy prawa cywilnego. Tę niedającą się wyjaśnić nierówność można rozstrzygnąć jedynie poprzez uznanie, że prawo do dodatkowego wynagrodzenia ma jednolity charakter prawny, a zatem niezależnie od organizacyjno-prawnej formy działania pracodawcy jest ono świadczeniem cywilnoprawnym bądź składnikiem wynagrodzenia pracowniczego. W wyroku z dnia 15 listopada 2013 roku $^{34}$ Sąd Najwyższy stwierdził, że wbrew określeniu ustawowemu umowa $\mathrm{w}$ przedmiocie dodatkowego wynagrodzenia, zawarta przez radcę prawnego z państwową jednostką organizacyjną, nie ma charakteru cywilnoprawnego. Implikuje to wniosek, że stanowi ona klauzulę autonomiczną umowy o pracę, jako że reguluje prawo do wynagrodzenia, będące elementem treści stosunku pracy.

Uogólniając tę część rozważań, należy postawić pytanie, czy kwestię cywilnoprawnego lub pracowniczego charakteru umowy rozstrzyga określenie ustawowe, czy też - nie poprzestając na tym określeniu — należy badać, jaki jest materialny charakter stosunku prawnego wytworzonego przez umowę. $\mathrm{W}$ razie przyjęcia tego drugiego rozwiązania, należałoby mówić o umowie „pozornie” cywilnoprawnej, która pozostaje $\mathrm{w}$ istocie umową prawa pracy, stanowiącą uzupełnienie umowy o pracę.

Należy dodać, że klauzule autonomiczne umów o pracę nie wyczerpują zakresu umów indywidualnego prawa pracy innych niż umowy zawiązujące stosunek pracy. Trafność tego stwierdzenia można wykazać na wzmiankowanym już przykładzie umowy o zakazie konkurencji po ustaniu stosunku pracy (art. $101^{2}$ k.p.). Zasadne jest stanowisko zaliczające tę umowę do instytucji prawa pracy. Relacje między stronami $\mathrm{w}$ fazie realizacyjnej tej umowy, przypadającej po ustaniu zatrudnienia, są bowiem wykładnikiem interesów pracodawcy i pracownika w okresie zawierania klauzuli konkurencyjnej, w którym adresat zakazu konkurencji ma status pracowniczy ${ }^{35}$. Umowie tej nie można jednak nadać charakteru klauzuli autonomicznej, ponieważ obowiązek nieprowadzenia działalności konkurencyjnej wobec byłego pracodawcy nie należy do treści stosunku pracy ${ }^{36}$.

Doniosłe znaczenie dla identyfikacji klauzul autonomicznych ma również przyjęta koncepcja stosunku pracy. W piśmiennictwie przedstawiono zapatrywanie opowiadające się za wąskim rozumieniem pojęcia stosunku pracy, który obejmuje jedynie te prawa i obowiązki jego stron, które zostały wysłowione wprost w art. 22 $\S 1$ k.p. ${ }^{37}$ Konsekwencją przyjęcia takiego założenia ${ }^{38}$ jest pozostawienie wielu nazwanych i nienazwanych umów prawa pracy poza granicami pojęcia klauzuli autonomicznej. Uwaga ta dotyczy między innymi umowy o zakazie konkuren-

34 Sygn. III PK 4/13, OSNP 2014, nr 10, poz. 142.

35 Por. P. Prusinowski, [w:] Zakaz konkurencji w prawie pracy, red. Z. Góral, Warszawa 2014, s. $52-56$.

\footnotetext{
36 A. Tomanek, op. cit., s. 40-41.

37 A. Sobczyk, Wolność pracy $i$ władza, Warszawa 2015, s. 245.

38 Założenie to nie jest podzielane przez autora niniejszego opracowania.
} 
cji w czasie trwania stosunku pracy (art. $101^{1}$ k.p.), a także umowy szkoleniowej (art. $103^{4}$ k.p. $)^{39}$, która rozwija pracodawczy obowiązek ułatwiania pracownikom podnoszenia kwalifikacji zawodowych (art. 94 pkt 6 k.p.).

Powstaje wreszcie zasygnalizowane wcześniej pytanie, czy dopuszczalne jest ujęcie w ramy klauzuli autonomicznej dowolnego elementu składającego się na prawa i obowiązki stron stosunku pracy. Stanowisko w tej sprawie zajęła Teresa Liszcz, stwierdzając, że pracodawca i pracownik nie mają pełnej swobody co do tego, jakie kwestie akcydentalne można „wyprowadzić” z umowy o pracę do klauzul autonomicznych. Strony nie mogą czynić przedmiotem nienazwanych klauzul autonomicznych takich dodatkowych ustaleń, które dotyczą obowiązków i praw stron stosunku pracy związanych z wykonywaniem przez pracownika umówionej pracy i świadczeniami z tytułu jej wykonywania ${ }^{40}$.

Należy zgodzić się z T. Liszcz, że pełna dowolność stron w określaniu materii prawnej klauzul autonomicznych byłaby zbyt daleko idąca. Jednocześnie jednak stanowisko tej autorki jest moim zdaniem nadmiernie ograniczające. Należy zwrócić uwagę, że klauzule autonomiczne mogą modyfikować takie elementy stosunku pracy, jak rodzaj pracy (umowa o powierzenie pracownikowi na okres przejściowy dodatkowego stanowiska lub funkcji) lub wynagrodzenie za pracę (umowa o dodatkowym wynagrodzeniu radcy prawnego z tytułu zastępstwa sądowego). Pomijając zatem sporne zagadnienie, czy elementy te, zwłaszcza umowne określenie wynagrodzenia za pracę i jego składników, stanowią essentialia negotii czy naturalia negotii umowy o pracę oraz $\mathrm{w}$ jakim zakresie podział ten jest przydatny do klasyfikacji treści tej umowy, trudno mówić o tym, że klauzula autonomiczna nie może obejmować elementów związanych bezpośrednio z wykonywaniem pracy i świadczeniami przysługującymi pracownikowi. Nie sposób również podzielić obaw cytowanej autorki, że większa swoboda przy określaniu treści klauzul autonomicznych spowoduje, że istotny zakres treści stosunku pracy będzie wymykać się przepisom kodeksu pracy (dział II) określającym zasady ich zmiany i utraty mocy obowiązującej. Takie ryzyko jest łagodzone zastosowaniem zasady uprzywilejowania pracownika (art. 18 k.p.), która w moim przekonaniu znajduje odniesienie do oceny treści klauzul autonomicznych ${ }^{41}$. Stosowanie tej zasady nie może być jednak pojmowane w ten sposób, że przepisy zamieszczone w dziale II k.p. (art. $30 \mathrm{n}$.) tworzą próg korzystności zakreślający granice umownego ustalenia sposobu rozwiązania klauzuli autonomicznej oraz zmiany jej treści. Przepisy te ustanawiają bowiem reguły odnoszące się do umowy o pracę, nie zaś do innych umów zawieranych między pracownikiem a pracodawcą ${ }^{42}$.

39 A. Sobczyk, [w:] Kodeks pracy. Komentarz, red. A. Sobczyk, Warszawa 2015, s. 533.

40 T. Liszcz, op. cit., s. 298.

41 Inaczej m.in. T. Liszcz, op. cit., s. 299. Swoje stanowisko przedstawiłem bliżej w opracowaniu Klauzule autonomiczne w umownym stosunku pracy, „Państwo i Prawo” 2013, nr 9, s. 42-43.

${ }^{42}$ Nie oznacza to pełnej dowolności w konstruowaniu formalnej sfery klauzuli autonomicznej, zwłaszcza jeżeli prowadziłoby to do rażącego naruszenia interesów pracownika. Warto jednak 
Akcydentalność klauzul autonomicznych nie powinna być wyjaśniana w kierunku utożsamiania jej z elementami „nieistotnymi” w strukturze stosunku pracy, ponieważ wszystkie kwestie pozostające w orbicie regulacji umownej mają charakter istotny dla kontraktujących stron. Chodzi raczej o to, że klauzula reguluje problematykę uboczną wobec głównych praw i obowiązków stron i/lub jej oddziaływanie jest przejściowe. W związku z tym strony nie mogą zmieniać na drodze klauzuli autonomicznej umownego rodzaju pracy (mogą jedynie wprowadzać uzupełnienie zasadniczych obowiązków pracownika) ani wynagrodzenia podstawowego (władne są tylko określać składniki dodatkowe, takie jak wynagrodzenie premiowe). Uwaga ta odnosi się również do rodzaju umowy o pracę, który powinien zostać ustalony w samej umowie przy uwzględnieniu kodeksowego numerus clausus (art. $25 \S 1$ k.p.), a także do zasad zmian i rozwiązywania umowy o pracę․ Klauzula nie może też modyfikować tych elementów treści stosunku pracy, traktowanych przez większość doktryny jako essentialia negotii umowy o pracę, które wynikają z definicji zamieszczonej w art. $22 \S 1$ k.p., co dotyczy w szczególności zobowiązania pracownika do wykonywania pracy na rzecz pracodawcy i pod jego kierownictwem oraz w miejscu i czasie przezeń wyznaczonym. W tej kwestii należy poczynić jednak spostrzeżenie, że niektóre przepisy prawa upoważniają strony do uregulowania w drodze klauzuli autonomicznej elementów treści stosunków pracy noszących cechy nietypowości ${ }^{44}$ lub odbiegających od zasad prawa pracy ${ }^{45}$.

\section{UWAGI KOŃCOWE}

Punktem wyjścia niniejszych rozważań była definicja klauzul autonomicznych sformułowana przez M. Święcickiego. Nazwa „klauzula autonomiczna” upowszechniła się w nauce i obrocie prawnym, co może być traktowane jako argument przemawiający za jej dalszym stosowaniem. Przedstawiona analiza pozwala stwierdzić, że przez klauzule autonomiczne należy rozumieć umowy prawa pracy zawierane przez pracownika i pracodawcę, regulujące elementy treści stosunku pracy. Umowy te są funkcjonalnie podrzędne wobec umowy o pracę, ale mają samodzielny byt prawny. Z tego względu nomenklatura ustalona przez

zauważyć, że większy zakres swobody w omawianej dziedzinie pozwala na wprowadzenie rozwiązań satysfakcjonujących zarówno pracodawcę, jak i pracownika, na przykład przez nadanie temu ostatniemu prawa do odstąpienia od klauzuli autonomicznej lub wypowiedzenia określonych jej warunków.

${ }^{43}$ M. Święcicki trafnie przyjmował, że postanowienie przedłużające ustawowy okres wypowiedzenia umowy o pracę stanowi dodatkowe zastrzeżenie umowne, nie zaś klauzulę autonomiczną —idem, op. cit., s. 183.

44 Zob. art. $67^{11} \S 2$ k.p. odnoszący się do umowy określającej warunki telepracy.

45 T. Kuczyński, Klauzule autonomiczne prawa pracy zwiazane z działalnościa podmiotów gospodarczych w warunkach rynkowych, „Przegląd Ustawodawstwa Gospodarczego” 1994, nr 6, s. 17. 
M. Święcickiego prowadzi do mylnych wniosków, co znajduje wyraz w przywołanych wypowiedziach doktrynalnych. W tej sytuacji zasadny wydaje się postulat ${ }^{46}$ zastąpienia jej terminem „umowy uzupełniające stosunek pracy” ${ }^{47}$.

We współczesnych realiach położenie prawne pracownika może być efektem oddziaływania palety umów i postanowień o umownym charakterze, określających jego sytuację prawną. Oprócz klauzul autonomicznych (umów uzupełniających) w przyjętym tutaj rozumieniu należy uwzględnić inne umowy prawa pracy oraz umowy cywilnoprawne łączące pracownika i pracodawcę. Celowe wydaje się zatem przemyślenie i przewartościowanie dotychczasowego spojrzenia na konsensualne „otoczenie” umowy o pracę. W tym kontekście doniosłe znaczenie ma sposób pojmowania swobody stron w kształtowaniu treści stosunku pracy i związanych z nim stosunków indywidualnego prawa pracy, której należy nadawać w mojej ocenie szeroki wymiar.

\section{AUTONOMOUS CLAUSES OF LABOUR CONTRACTS - CONCEPTUAL ISSUES}

\section{Summary}

The starting point of this article is the notion of an autonomous clause which was introduced into the theory of Polish labour law by Marcin Święcicki. The author of the text maintains that an employer and an employee have the freedom to agree upon autonomous clauses of a labour contract. The above-mentioned clauses are separate contracts which are amended and terminated according to rules which are different from those relating to the main contract (contract of labour). The autonomous clauses form rights and obligations of the parties of the labour contract as opposed to other individual labour-law contracts and civil-law contracts. The limitations of the subject-matter of autonomous clauses should be deduced from the legal nature of the discussed clauses and the main labour contract.

Keywords: autonomous clause, labour relation, labour contract, civil law contract

\section{BIBLIOGRAFIA}

Brzozowski A., [w:] System Prawa Prywatnego, t. 5. Prawo zobowiąań-część ogólna, red. E. Łętowska, Warszawa 2006.

Florek L., Ustawa i umowa w prawie pracy, Warszawa 2010.

Gawlik B., Umowy mieszane - konstrukcja i ocena prawna, „Palestra” 1974, nr 5.

Jaśkowski K., [w:] Kodeks pracy. Komentarz. Ustawy towarzyszące z orzecznictwem, red. K. Jaśkowski, E. Maniewska, Warszawa 2019.

Jończyk J., Prawo pracy, Warszawa 1984.

46 Postulat ten został sformułowany przez J. Stencel, op. cit., s. 116-117.

47 Poza zakresem niniejszego opracowania pozostawiono problem stosowania klauzul autonomicznych w pozaumownych stosunkach pracy. 
Kubot Z., Pozycja prawna stron w umownym stosunku pracy, Wrocław 1978.

Kubot Z., Umowa nienazwana jako podstawa powstania stosunku pracy?, [w:] Prawo pracy, zabezpieczenie społeczne (z aktualnych zagadnień), red. B.M. Ćwiertniak, Opole 2001.

Kuczyński T., Klauzule autonomiczne prawa pracy zwiąane z działalnościa podmiotów gospodarczych w warunkach rynkowych, „Przegląd Ustawodawstwa Gospodarczego” 1994, nr 6.

Liszcz T., [w:] System Prawa Pracy, t. 2. Indywidualne prawo pracy. Część ogólna, red. G. Goździewicz, Warszawa 2017.

Machnikowski P., [w:] System Prawa Prywatnego, t. 5. Prawo zobowiązań - część ogólna, red. E. Łętowska, Warszawa 2006.

Patulski A., Zatrudnianie i wynagradzanie kadry menedżerskiej średniego i wyższego szczebla, Gdańsk 2001.

Piotrowski W., Stosunek pracy, Poznań 1977.

Prusinowski P., [w:] Zakaz konkurencji w prawie pracy, red. Z. Góral, Warszawa 2014.

Prusinowski P., Nienazwane umowy zawierane przez strony stosunku pracy, „Monitor Prawa Pracy” 2011, nr 20.

Radwański Z., Teoria umów, Warszawa 1977.

Sobczyk A., Wolność pracy $i$ władza, Warszawa 2015.

Sobczyk A., [w:] Kodeks pracy. Komentarz, red. A. Sobczyk, Warszawa 2015.

Stelina J., [w:] Prawo pracy, red. J. Stelina, Warszawa 2018.

Stencel J., Zakaz konkurencji w prawie pracy, Warszawa 2001.

Szubert W., Zarys prawa pracy, Warszawa 1976.

Święcicki M., Prawo pracy, Warszawa 1968.

Tomanek A., Charakter prawny klauzuli konkurencyjnej (art. 101² k.p.), „Przegląd Sądowy” 2014, nr 10.

Tomanek A., Klauzule autonomiczne w umownym stosunku pracy, „Państwo i Prawo” 2013, nr 9.

Wagner B., Zakres swobody umów w pracowniczym stosunku pracy, Kraków 1986.

Wagner B., Zasada swobody umów w prawie pracy, „Państwo i Prawo” 1987, nr 6.

Zieleniecki M., [w:] Prawo pracy, red. J. Stelina, Warszawa 2018.

Zieliński T., , Umowy nienazwane” w grupowym systemie czasu pracy, „Ruch Prawniczy, Ekonomiczny i Społeczny" 1988, nr 1.

Zieliński T., Glosa do uchwaly SN z 22 października 1987 r., III CZP 55/87, „Państwo i Prawo” 1991, $\mathrm{nr} 2$.

Ziembiński Z., Problemy podstawowe prawoznawstwa, Warszawa 1980. 